\title{
Mif deficiency promotes adiposity in fructose-fed mice
}

\author{
Ljupka Gligorovska, Biljana Bursać, Sanja Kovačević, Nataša Veličković, Gordana Matić and Ana Djordjevic \\ Department of Biochemistry, Institute for Biological Research 'Siniša Stanković', University of Belgrade, Belgrade, Serbia
}

Correspondence should be addressed to A Djordjevic: djordjevica@ibiss.bg.ac.rs

\begin{abstract}
The macrophage migration inhibitory factor (MIF) is a proinflammatory cytokine involved in inflammation, regulation of energy metabolism and glucocorticoid action. Chronic lowgrade inflammation may be caused by fructose intake, contributing to visceral adipose tissue (VAT) dysfunction. Since MIF is a known antagonist of glucocorticoid signaling, and deregulated glucocorticoid signaling can contribute to lipid metabolism disturbances, we hypothesized that altered MIF signaling might underlie fructose-induced adiposity through glucocorticoid action. We analyzed physiological and biochemical parameters, adipose tissue histology, insulin sensitivity and lipid metabolism in WT and MIF-/- C57BI/6] mice consuming 20\% fructose solution for 9 weeks. Glucocorticoid prereceptor metabolism and glucocorticoid receptor (GR) protein level were examined in VAT, together with the expression of glucocorticoid-target genes involved in lipid metabolism. The expression of adipogenic and lipogenic transcriptional regulators peroxisome proliferator-activated receptor gamma (PPARG) and sterol regulatory element-binding protein 1c (SREBP1C) was also assessed. Results showed disturbed insulin sensitivity in all MIF-/- mice, regardless of the diet. Mice on fructose diet had increased energy intake, but increased visceral adiposity and enlarged adipocytes were observed only in fructose-fed MIF-/- mice. Increased VAT corticosterone level and 11 beta-hydroxysteroid dehydrogenase type 1, hexose-6-phosphate dehydrogenase and GR protein levels were observed in the same animals, together with induced expression of examined lipogenic genes and accumulation of PPARG and SREBP1c. In conclusion, the results showed that dietary fructose was associated with increased visceral adiposity through activation of GR-regulated lipogenic genes, but only in the absence of MIF, which set the state of hyperinsulinemia and insulin resistance.
\end{abstract}

\section{Key Words}

- macrophage migration inhibitory factor

- insulin resistance

- fructose

- glucocorticoids

- visceral adipose tissue

- lipid metabolism

\section{Introduction}

The rate of fructose consumption has been increasing worldwide and it is considered to be a contributing factor to the rising prevalence of obesity and metabolic disturbances. There are evidence from human and animal studies supporting the ability of high-fructose diet to upregulate lipid metabolism leading to dyslipidemia, insulin resistance and type 2 diabetes (T2D) (Basciano et al. 2005,
Tappy \& Le 2010). Excess fructose intake can also contribute to intra-abdominal adiposity and dysfunction of the adipose tissue, resulting in the infiltration of immune cells and development of chronic low-grade inflammation (Monteiro \& Azevedo 2010).

Macrophage migration inhibitory factor (MIF) is a pleiotropic ubiquitously expressed cytokine that 
regulates proinflammatory response and is associated with numerous inflammatory and autoimmune diseases including T2D and obesity (Yabunaka et al. 2000, Church et al. 2005, Cvetkovic et al. 2005). The elevation of MIF plasma concentration and MIF mRNA level found in obese subjects and animal models was positively associated with elevated plasma free fatty acid (FFA) concentrations and increased BMI (Skurk et al. 2005, Finucane et al. 2012, Veličković et al. 2013). A growing body of evidence indicates that MIF has a role in energy metabolism in the adipose tissue and liver, since its expression in these tissues is regulated by glucose and insulin (Sakaue et al. 1999, Morrison \& Kleemann 2015). Mif deletion may contribute to the development of systemic insulin resistance through deregulation of glucose metabolism (Atsumi et al. 2007, Saksida et al. 2013, Nikolic et al. 2013a). However, the data are still inconclusive, since studies are reporting that Mifknockout mice display improved insulin sensitivity and glucose tolerance (Verschuren et al. 2009, Kleemann \& Bucala 2010).

Although MIF synthesis and secretion are upregulated by the glucocorticoid hormones (GCs), MIF acts as the counter-regulator of GC anti-inflammatory action to control the magnitude of the immune response (Calandra \& Bucala 1997). Systemic hypercortisolemia and overexpression of enzymes converting inactive forms of GCs to active ones, 11-beta-hydroxysteroid dehydrogenase type-1 (11BHSD1) and hexose-6phosphate dehydrogenase (H6PDH), were previously associated with increased accumulation of visceral adipose tissue (VAT) (Seckl et al. 2004, Mariniello et al. 2006). GCs affect carbohydrate and lipid metabolism through hormone-dependent transcription regulator, glucocorticoid receptor (GR) (Peckett et al. 2011). Depending on nutritional and energy state, GCs can dually affect lipid metabolism. These effects can be opposite to insulin action, since GR directly regulates transcription of lipolytic enzymes, adipose tissue triglyceride lipase (ATGL) and hormone-sensitive lipase (HSL) (Lee et al. 2014). On the other hand, when insulin levels are high, GCs and insulin synergistically increase expression of lipogenic genes, including lipoprotein lipase $(L p l)$, fatty acid synthase (Fas), acetyl-CoA carboxylase (Acc) and phosphoenolpyruvate carboxykinase (Pepck) (Chakravarty et al. 2005, Campbell et al. 2011, Peckett et al. 2011). Besides GR, a number of insulin-regulated transcriptional factors are engaged in lipid metabolism and adipose tissue development. The examples are sterol regulatory element-binding protein 1c (SREBP1c), responsible for triglyceride biosynthesis, as well as

(c) 2019 Society for Endocrinology Published by Bioscientifica Ltd. Printed in Great Britain
PPARG involved in adipocyte differentiation (Rosen \& Spiegelman 2001, Eberlé et al. 2004).

Circulating MIF levels and intracellular GCs are shown to be elevated in obese subjects; however, their role and interaction in changes of lipid metabolism and insulin resistance induced by high-fructose diet remain elusive. The aim of this study was to investigate whether genetic deletion of Mif results in GC-mediated disturbances of glucose and lipid metabolism in VAT of male mice fed with 20\% fructose-enriched diet. Glucose metabolism was assessed through analysis of systemic insulin sensitivity, while lipid metabolism was analyzed at the level of visceral adiposity, VAT histology and the expression of GC-target genes involved in lipogenesis. Besides GR signaling in VAT, the expression of PPARG and SREBP1c, as key transcriptional regulators involved in adipogenesis and lipogenesis, was also examined.

\section{Materials and methods}

\section{Animals and treatment}

The generation of homozygous Mif gene-deficient (MIF-l-) mice on C57BL/6J background has been described elsewhere (Fingerle-Rowson et al. 2003). Breeder mice, both $\mathrm{MIF}^{-/-}$(on a C57BL/6J background) and WT C57BL/6J mice were a kind gift from Dr Christine Metz (Laboratory of Medicinal Biochemistry, The Feinstein Institute for Medical Research, North Shore LIJ Health System, NY) to Dr Stanislava Stosic-Grujicic from the Institute for Biological Research 'Siniša Stanković'. All animals were bred under standard pathogen-free laboratory conditions in the Animal Facility of the Institute. During 9 weeks, mice were kept in a temperature-controlled room $\left(22 \pm 2^{\circ} \mathrm{C}\right)$ with a 12 -h light/darkness cycle (lights on at 07:00 h). The 2-month-old animals were divided into four experimental groups ( $n=12$ animals per group): WT and $\mathrm{MIF}^{-1-}$ mice had standard diet (commercial chow and drinking water available ad libitum), while WT and $\mathrm{MIF}^{-/-}$mice on fructose-rich diet had ad libitum access to commercial chow and to $20 \%$ fructose solution instead of drinking water (WT FrD and MIF-/- FrD, respectively). The detailed composition of the diet was described previously (Veličković et al. 2013). The animals were housed 4 per cage, and daily food and fluid intake per cage were measured during 9 weeks. Body mass was measured weekly. Daily energy intake for mice on standard diet was calculated as food weight $(\mathrm{g})$ per cage $\times 11 \mathrm{~kJ}$, while energy intake for mice on fructose diet was calculated as sum of calories ingested as food and fructose solution 
(food weight $(\mathrm{g})$ per cage $\times 11 \mathrm{~kJ}+$ fructose intake $(\mathrm{mL})$ per cage $\times 3.44 \mathrm{~kJ})$. All animal procedures were in compliance with the EEC Directive 2010/63/EU on the protection of animals used for experimental and other scientific purposes and were approved by the Ethical Committee for the Use of Laboratory Animals of the Institute for Biological Research 'Siniša Stanković', University of Belgrade.

\section{Intraperitoneal glucose (IP-GTT) and insulin tolerance tests (IP-ITT)}

IP-GTT was performed 3 days before the end of the treatment. Mice were fasted overnight and glucose challenge was given intraperitoneally $(2 \mathrm{~g} / \mathrm{kg})$ without anesthesia in order to avoid the effect of anesthetic on glucose level and kinetics of glucose disposal. In order to determine glucose concentration, blood samples were taken from the tip of the tail at $0,15,30,60,90$ and $120 \mathrm{~min}$ after injection. For IP-ITT, mice were fasted for $4 \mathrm{~h}$ prior to the test. Blood glucose was determined at $0,15,30,60,90$ and $120 \mathrm{~min}$ after the insulin injection $(0.75 \mathrm{IU} / \mathrm{kg})$. The blood glucose concentration was measured using AccuChek Active strips (F. Hoffmann-La Roche AG). The area under the concentration vs time curve (AUC glucose $0-120 \mathrm{~min}, \mathrm{mmol} / \mathrm{L}$ vs min) was calculated by the trapezoidal rule.

\section{Blood sample collection and determination of plasma parameters}

Mice were killed by rapid decapitation after overnight fasting. Trunk blood was collected into EDTA-containing tubes. Blood glucose and triglycerides were measured by Accutrend strips (F. Hoffmann-La Roche AG).

Plasma was prepared by low-speed centrifugation $(1600 \mathrm{~g} / 10 \mathrm{~min})$ and stored at $-20^{\circ} \mathrm{C}$ for subsequent processing. FFAs were determined by the Semi-auto Chemistry Analyzer (Rayto 1904C) using Randox NEFA kit (Randox Laboratories Ltd, Crumlin, UK).

Leptin concentrations were determined by Mouse/Rat Leptin Quantikine ELISA kit according to manufacturer's instructions (R\&D Systems). Absorbance at $450 \mathrm{~nm}$ (reference $570 \mathrm{~nm}$ ) was measured spectrophotometrically (Multiskan Spectrum, Thermo, Finland). Leptin concentrations were determined using regression analysis curvefitting method (Prism, GraphPad Software) and given as $\mathrm{pg} / \mathrm{mL}$. The assay sensitivity was $22 \mathrm{pg} / \mathrm{mL}$, while intraassay and inter-assay CVs were 3.8 and 5.0\%, respectively.

Insulin concentration was determined by RIA method, using mouse insulin standards (INEP, Belgrade, Serbia).
The assay sensitivity was $0.6 \mathrm{mIU} / \mathrm{L}$ and intra-assay coefficient of variation was $5.24 \%$.

\section{Isolation of visceral adipose tissue}

VAT was excised, washed by $0.9 \% \mathrm{NaCl}$ solution, weighed and frozen in liquid nitrogen. Excised VAT consisted of gonadal, retroperitoneal and perirenal depots, representing the pooled fat of the intra-abdominal cavity, which was previously correlated with development of insulin resistance and metabolic syndrome, especially in male rodents (Wajchenberg 2000, Bjørndal et al. 2011).

For histological analysis, part of the gonadal VAT was excised and fixed in $10 \%$ neutral formalin for $24 \mathrm{~h}$, dehydrated in ethanol gradient, cleared in xylene and embedded in paraffin. Gonadal fat pads were chosen for the histological analysis not only because they are the largest and most readily accessible fat pads in mice (Chusyd et al. 2016), but also because they are the primary storage depot in C57BL/6J mice, expanding initially in diet-induced obesity (van Beek et al. 2015).

\section{Histological analysis of VAT}

VAT blocks were sectioned at $10 \mu \mathrm{m}$ thickness and stained with hematoxylin-eosin. Morphometric analysis was carried on workstation comprising microscope (Olympus) equipped with a charge-coupled device video camera (PixeLINK, Ottawa, Canada). The system was controlled by the newCAST software package (Visiopharm Integrator System, version 3.2.7.0, Visiopharm, Denmark). Images were analyzed by Adiposoft software (Galarraga et al. 2012). The cell diameter and sectional area were measured using three images per section (20x magnification), three sections per animal and five animals per group.

\section{Preparation of cytoplasmic fraction and determination of VAT corticosterone concentrations}

For the preparation of cytoplasmic fraction from VAT, tissue was homogenized $(\mathrm{w} / \mathrm{v}=1: 1)$ in ice-cold homogenization buffer $(20 \mathrm{mM}$ Tris-HCl, pH 7.2, 10\% glycerol, $50 \mathrm{mM} \mathrm{NaCl}, 1 \mathrm{mM}$ EDTA-Na ${ }_{2}, 1 \mathrm{mM}$ EGTA-Na ${ }_{2}$, $2 \mathrm{mM}$ DTT, protease and phosphatase inhibitors). The cell lysate was filtered through gauze and centrifuged at low speed $\left(2000 \mathrm{~g}, 15 \mathrm{~min}, 4^{\circ} \mathrm{C}\right)$. The resulting supernatant was centrifuged $\left(10,000 \mathrm{~g}, 25 \mathrm{~min}, 4^{\circ} \mathrm{C}\right)$, recentrifuged $\left(150,000 \mathrm{~g}, 90 \mathrm{~min}, 4^{\circ} \mathrm{C}\right.$, Beckman ultracentrifuge $)$ and the final supernatant was used as cytoplasmic fraction. Lowry method was used for the determination of protein concentration (Lowry et al. 1951). 
VAT corticosterone (CORT) was assessed using Corticosterone High Sensitivity EIA kit according to manufacturer's instructions (Immunodiagnostic Systems LTD, Tyne and Wear, UK). Absorbance at $450 \mathrm{~nm}$ (reference $650 \mathrm{~nm}$ ) was measured spectrophotometrically (Multiskan Spectrum, Thermo, Finland). CORT concentrations were determined using four parameter logistic (4PL) curvefitting method (Prism, GraphPad Software) and given as $\mathrm{ng} / \mathrm{mg}$ of protein. The assay sensitivity was $0.17 \mathrm{ng} / \mathrm{mL}$, while intra-assay and inter-assay CVs were 5.9 and $8.9 \%$, respectively.

\section{RNA extraction and reverse transcription}

VAT total RNA was isolated using TRIzol (AmBion, Life Technologies). Samples were centrifuged at $12,000 \boldsymbol{g}$ for $15 \mathrm{~min}$ at $4^{\circ} \mathrm{C}$ after homogenization. RNA was precipitated with isopropanol. Qualitative and quantitative evaluation of the isolated RNA was performed on $2 \%$ agarose gel and spectrophotometrically (OD 260/280>1.8 was considered satisfactory). Reverse transcription was performed using a High-Capacity cDNA Reverse Transcription Kit (Applied Biosystems) according to manufacturer's instructions and the cDNAs were stored at $-70^{\circ} \mathrm{C}$ until use.

\section{Real-time PCR}

The expression of genes was analyzed using Power SYBR Green PCR Master Mix. Specific primers (Applied Biosystems) were used to amplify $\mathrm{Hsl}$ selectively: F 5'-GGC TCA CAG TTA CCA TCT CAC C-3', R 5'-GAG TAC CTT GCT GTC CTG TCC-3'; Atgl: F 5'-AAC ACC AGC ATC CAG TTC AA-3', R 5'-GGT TCA GTA GGC CAT TCC TC-3'; Pepck: F 5'-AAC TGT TGG CTG GCT CTC-3', R 5'-GAA CCT GGC GTT GAA TGC-3'; Lpl: F 5'-TTC CAG CCA GGA TGC AAC A-3', R 5'-GGT CCA CGT CTC CGA GTC C-3'; Acc: F 5'GAG AGG GGT CAA GTC CTT CC-3', R 5'-CTG CTG CCG TCA TAA GAC AA-3'; Fas: F 5'-TTG CTG GCA CTA CAG AAT GC-3', R 5'-AAC AGC CTC AGA GCG ACA AT-3'. Normalization of cDNA was performed using previously validated (Djordjevic et al. 2012) hypoxanthine guanine phosphoribosyl transferase (Hprt) as endogenous control (F 5'-TCC TCC TCA GAC CGC TTT T-3', R 5'-CCT GGT TCA TCA TCG CTA ATC-3'). All reactions were performed in triplicate in $25 \mu \mathrm{L}$ volume containing $20 \mathrm{ng}$ of cDNA template using QuantStudio 3 (Applied Biosystems). Thermal cycling conditions were 2-min incubation at $50^{\circ} \mathrm{C}, 10 \mathrm{~min}$ at $95^{\circ} \mathrm{C}$ followed by 60 cycles of $95^{\circ} \mathrm{C}$ for $15 \mathrm{~s}$ and $60^{\circ} \mathrm{C}$ for $60 \mathrm{~s}$. Melting curve analyses were performed at the end of every experiment to confirm the formation of a single PCR product. Relative quantification of gene expression was performed using the comparative $2^{-\Delta \Delta C t}$ method, where $\Delta \mathrm{Ct}$ represents the difference between $\mathrm{Ct}$ value of target gene and the endogenous control. The results were analyzed by QuantStudio Design and Analysis Software v1.4.0 (Applied Biosystems) with a confidence level of $95 \%(P \leq 0.05)$.

\section{Sample preparation}

For the preparation of VAT total protein fraction, TRIzol was used according to the manufacturer's instruction. After aqueous phase separation for RNA precipitation, the remaining organic phase was centrifuged at $2000 \boldsymbol{g}$ for $5 \mathrm{~min}$ at $4^{\circ} \mathrm{C}$ after adding ethanol. Protein fraction was precipitated from phenol-ethanol supernatant, using acetone and centrifuged at $12,000 \boldsymbol{g}$ for $10 \mathrm{~min}$ at $4^{\circ} \mathrm{C}$. The protein pellets were dispersed in $0.3 \mathrm{M}$ guanidine hydrochloride in 95\% ethanol with $2.5 \%$ glycerol by sonication on ice and washed in $0.3 \mathrm{M}$ guanidine hydrochloride in $95 \%$ ethanol with $2.5 \%$ glycerol. After sedimenting the protein by centrifugation at $8000 \mathrm{~g}$ for $5 \mathrm{~min}$ at $4^{\circ} \mathrm{C}$, pellets were dispersed in the lysis buffer containing $2.5 \mathrm{mM}$ Tris- $\mathrm{HCl} \mathrm{pH} 6.8,2 \%$ SDS, $10 \%$ glycerol and $50 \mathrm{mM}$ DTT. Samples were stored at $-70^{\circ} \mathrm{C}$ until use.

\section{Western blot analysis}

Proteins concentration was measured using Lowry method (Lowry et al. 1951) and 60 $\mu$ g of proteins were subjected to electrophoresis on 7.5\% SDS-PAGE. After transfer to PVDF membrane (Immobilon-FL membrane, Millipore), using a Transblot system (Bio-Rad Laboratories), the unbound sites were blocked ( $1 \mathrm{~h}$ with $2 \%$ non-fat dry milk) and the membranes were probed with specific primary rabbit polyclonal antibodies for anti-phospho-p38 Tyr 182 (1:750) (sc-7975-R, Santa Cruz Biotechnology), anti-p38 MAPK (1:500) (sc-535, Santa Cruz Biotechnology), anti-GR (1:500) (sc-8992, Santa Cruz Biotechnology), anti-11BHSD1 (1:1000) (ab393364, Abcam), anti-H6PDH (1:1000) (sc-67394, Santa Cruz Biotechnology), antiSREBP1c (1:500) (sc-366, Santa Cruz Biotechnology) and mouse monoclonal anti-PPARG (1:1000) (sc-7273, Santa Cruz Biotechnology). Monoclonal mouse anti-B-actin antibody (1:10,000) (AC-15, Sigma-Aldrich) was used as a loading control. Blots were developed with secondary ECL anti-rabbit IgG HRP-linked whole antibody (1:10,000) (Amersham Pharmacia Biotech) or with anti-mouse IgG HRP-linked whole antibody (1:20,000) (ab97046, Abcam). Signal was developed using enhanced chemiluminescence 
(ECL) and densitometry of protein bands on X-ray films (Kodak, Rochester, USA) was performed by Image J software (NIH).

\section{Statistical analyses}

The data are presented as means \pm s.E.M. To determine the effects of Mif deficiency and fructose diet, as well as their interaction, two-way ANOVA followed by post hoc Tukey test was used. A probability level less than 0.05 was considered statistically significant. Statistical analyses were performed by Statistica 10 Software (Stat Soft. Inc., Tulsa, USA).

\section{Results}

\section{Physiological measurements}

No difference in food intake was observed between WT and $\mathrm{MIF}^{-/-}$mice on standard diet; however, both groups on fructose diet showed a typical decrease in food intake, paralleled with increased liquid intake (Table $1, P<0.001$ ). As expected, all mice on fructose diet had increased energy intake compared to both WT and $\mathrm{MIF}^{-/-}$animals $(P<0.001)$.

Despite increased energy intake, body mass and weight gain of fructose-fed mice were not significantly different from the animals on the standard diet (Fig. 1A). Interestingly, mass of VAT was higher in Mif-deficient mice in comparison to WT animals (Fig. 1B, $P<0.05$ ), while fructose-fed $\mathrm{MIF}^{-/-}$mice had significantly more VAT than both WT $(P<0.001)$ and WT mice consuming fructose $(P<0.01)$. However, VAT-to-body mass ratio, taken as an index of visceral adiposity, was significantly increased only in Mif-deficient mice on fructose diet in comparison to WT groups on standard and fructose diet (Fig. 1C, $P<0.001$ and $P<0.01$, respectively), as well as to $\mathrm{MIF}^{-/-}$mice on standard diet $(P<0.05)$.

\section{Measurements of plasma triglycerides, FFA, leptin and insulin sensitivity parameters}

Both plasma triglycerides and FFA were the same in all experimental groups (see Table 1). Leptin concentrations were significantly higher in $\mathrm{MIF}^{-/-}$mice, regardless of the diet, when compared to the WT animals $(P<0.05)$.

As shown in Table 2, MIF-l- mice had significantly higher fasting glucose than WT animals $(P<0.05)$, while in fructose-fed $\mathrm{MIF}^{-/-}$mice glucose level was higher

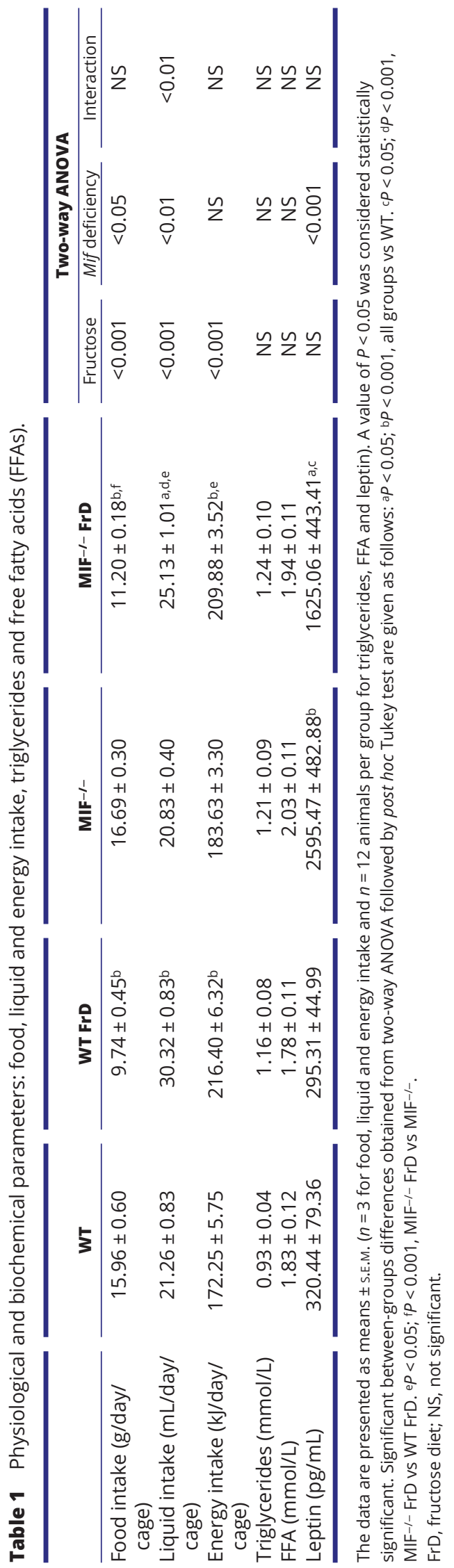



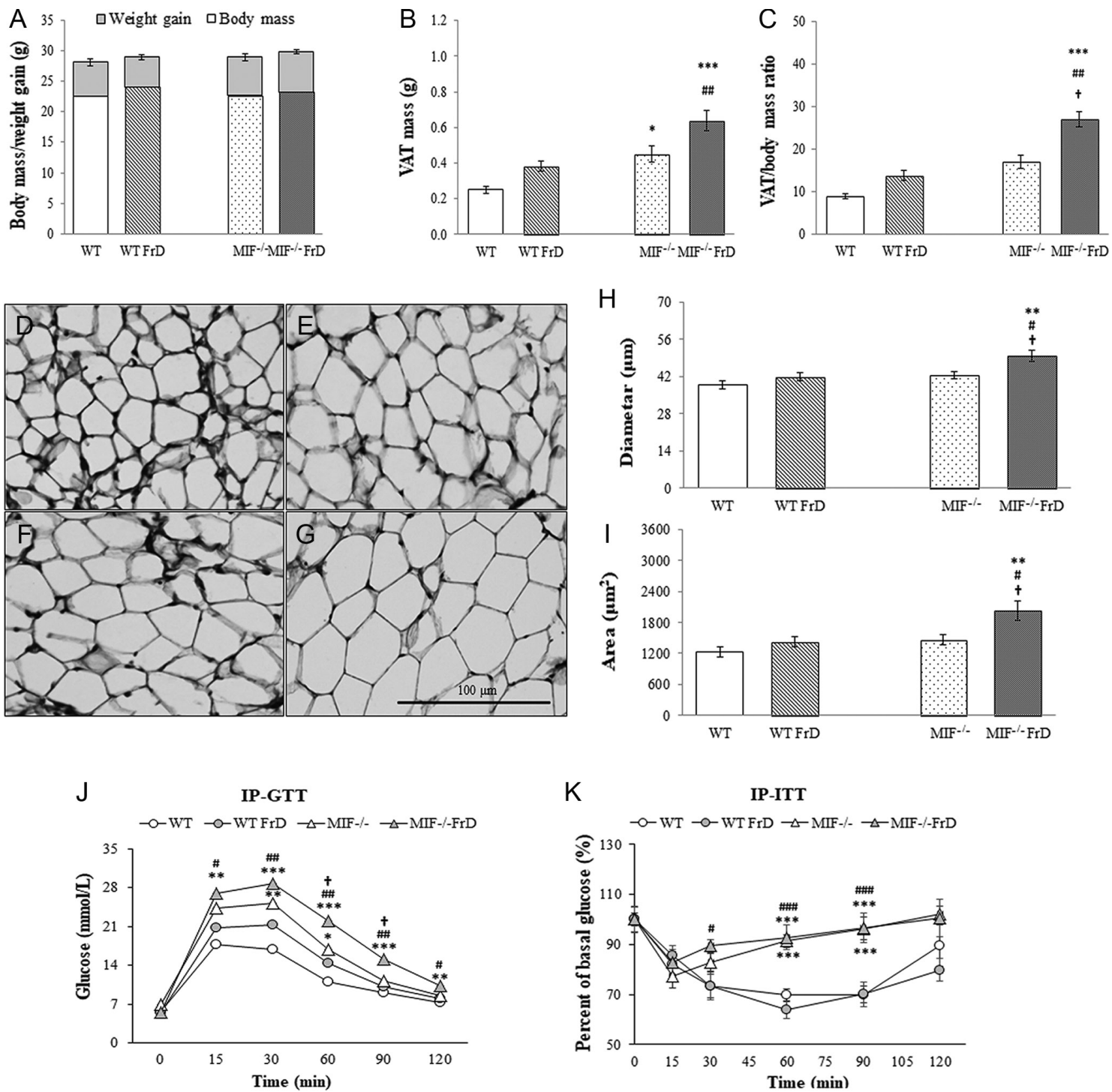

Figure 1

Physiological and biochemical parameters. Body mass, VAT mass and histological analysis: Data for body mass and weight gain (A), VAT mass (B) and VAT/body mass ratio (C) are presented as mean \pm S.E.M. ( $n=12$ animals per group). Representative hematoxylin-eosin staining of VAT sections from

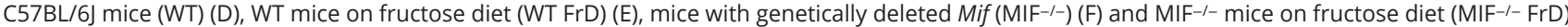
(G) (magnification $\times 20$, bar $=100 \mu \mathrm{m})$. Morphometric data on adipocyte cell diameter $(\mathrm{H})$ and area $(\mathrm{I})$ are presented as mean \pm S.E.M. $(100$ adipocytes per section, three sections per animal and five animals per group). A value of $P<0.05$ was considered statistically significant. Two-way ANOVA showed significant effect of fructose on VAT mass $(P<0.01)$, VAT/body mass ratio $(P<0.05)$, as well as on the adipocyte cell diameter and area $(P<0.01)$. Mif deficiency also had significant effect on both VAT and VAT/body mass ratio $(P<0.001)$, as well as on the adipocyte cell diameter $(P<0.01)$ and area $(P<0.05)$. Significant between-group differences from post hoc Tukey test are given as follows: ${ }^{*} P<0.05,{ }^{* *} P<0.01,{ }^{* * *} P<0.001$, all groups vs WT; $\# P<0.05$, $\# \#<<0.01, \mathrm{MIF}^{-1-}$ FrD vs WT FrD; ${ }^{\dagger} P<0.05, \mathrm{MIF}^{-1-}$ FrD vs MIF-l-. Intraperitoneal tests of glucose and insulin tolerance IP-GTT (J) and IP-ITT (K): After determination of fasting glucose concentrations, animals were challenged with intraperitoneal injection of glucose $(2 \mathrm{~g} / \mathrm{kg})$ or insulin $(0.75 \mathrm{IU} / \mathrm{kg})$. Blood glucose was measured 15, 30, 60, 90, and 120 min after injection, and glucose concentration vs time was plotted for C57BL/6] mice (WT), WT mice on

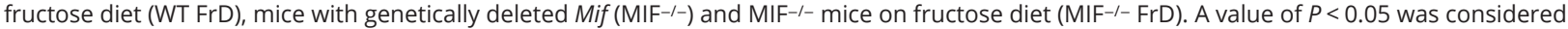
statistically significant. Data are presented as mean \pm S.E.M. $(n=12$ animals per group). Significant between-group differences from post hoc Tukey test are

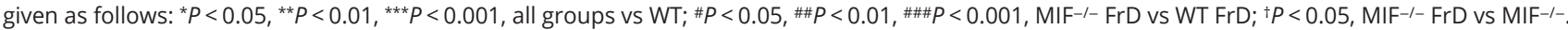

only in comparison to WT mice consuming fructose $(P<0.01)$. Increased insulin was present in $\mathrm{MIF}^{-/-}$mice in comparison to WT $(P<0.05)$, while $\mathrm{MIF}^{-/-}$mice on fructose diet had higher insulin level than WT mice on both standard $(P<0.01)$ and fructose diet $(P<0.05)$.
Insulin sensitivity was estimated by IP-GTT and IP-ITT tests and the results showed that both fructose diet and Mif deficiency contributed to its disturbance (Table 2). Namely, $\mathrm{MIF}^{-/-}$mice showed worse profiles for both GTT and ITT AUC values compared to WT animals 
(Fig. 1J and $\mathrm{K}, P<0.001$ ). While fructose feeding worsened glucose tolerance in both genotypes (Fig. $1 \mathrm{~J}$ and Table 2, $P<0.001)$, it had no impact on ITT AUC values beyond the effect of Mif deficiency (Fig. 1K and Table 2).

\section{Histological and morphometrical analysis of VAT}

VAT histological analysis revealed large adipocytes in $\mathrm{MIF}^{-/-}$mice on fructose diet (Fig. 1D, E, F, G, H and I). Morphometrical analysis showed that both adipocyte cell diameter and area (Fig. $1 \mathrm{H}$ and I) were significantly increased in fructose-fed $\mathrm{MIF}^{-/-}$mice in comparison to both WT mice on standard $(P<0.01)$ and fructose diet $(P<0.05)$, as well as in comparison to Mif-deficient mice on standard diet $(P<0.05)$.

\section{Signaling pathway of p38 kinase in VAT}

Elevation of total p38 levels were observed in both fructose-fed groups, as well as in standard-fed $\mathrm{MIF}^{-/-}$mice vs WT animals (Fig. 2, $P<0.001$ ). Also, $\mathrm{MIF}^{-/-}$animals on fructose diet had elevated total p38 protein level compared to the WT on the same dietary regimen $(P<0.001)$, while the level of this protein was decreased in comparison to $\mathrm{MIF}^{-/-}$animals on standard diet $(P<0.001)$. On the other hand, a significant increase of phosphorylated p38, as well as the ratio of phosphorylated to total p38 level, was observed in all fructose-fed animals (Fig. 2, $P<0.05$ ), which indicates the impact of fructose diet, without the effect of the genotype.

\section{Glucocorticoid prereceptor metabolism and signaling}

VAT glucocorticoid signaling was examined at the level of prereceptor metabolism (protein levels of 11BHSD1 and H6PDH enzymes and intracellular level of CORT) and at GR protein level. As shown in Fig. 3A and B, an increase of 11BHSD1 and H6PDH was observed in $\mathrm{MIF}^{-/-}$animals on fructose diet in respect to WT $(P<0.001$ and $P<0.01$, respectively) and $\mathrm{MIF}^{-/-}$mice on standard diet $(P<0.01)$.

In line with enhanced prereceptor metabolism, increased VAT CORT (Fig. 3C) was observed in fructosefed $\mathrm{MIF}^{-/-}$mice in comparison to both normally fed and fructose-fed WT mice $(P<0.05)$, as well as in comparison to standard-fed $\mathrm{MIF}^{-/-}$animals $(P<0.01)$. In addition, GR protein level was elevated only in fructose-fed $\mathrm{MIF}^{-/-}$mice compared to WT group (Fig. 3D, $P<0.05$ ).

\section{Lipid metabolism in VAT}

The results showed changes in the expression of GR-target genes involved in VAT lipid metabolism in fructose-fed 

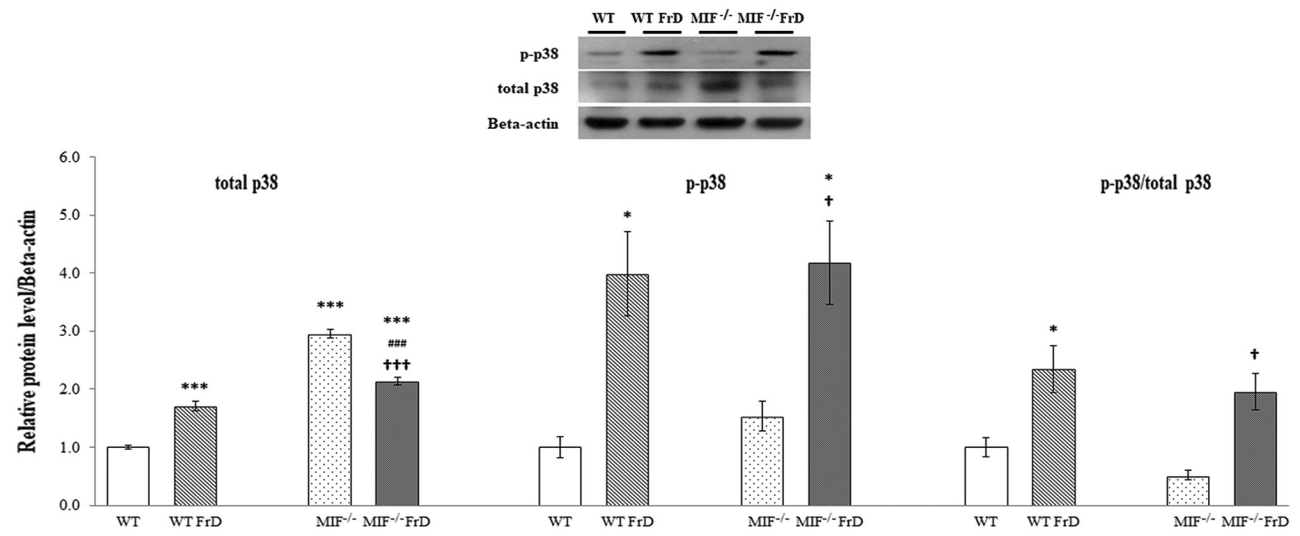

Figure 2

Phosphorylated and total p38 kinase and their ratio in the VAT. Representative Western blots and relative quantification of total and phospho-p38 kinase and their ratio in the total protein extract of VAT from C57BL/6] mice (WT), WT mice on fructose diet (WT FrD), mice with genetically deleted Mif (MIF-/-) and $\mathrm{MIF}^{-1-}$ mice on fructose diet (MIF-l- FrD). Immunoreactivities of total and phosphorylated p38 are normalized to Beta-actin as loading control and the data are presented as mean \pm S.E.M. ( $n=12$ animals per group). A value of $P<0.05$ was considered statistically significant. Two-way ANOVA showed that total p38 protein level was significantly affected by Mif deficiency $(P<0.001)$ and its interaction with fructose diet $(P<0.001)$. Phosphorylation and activity of p38 was significantly affected only by fructose $(P<0.001)$. Significant between-group differences from post hoc Tukey test are given as follows: ${ }^{*}<<0.05$, ${ }^{* * *} P<0.001$, all groups vs WT; \#\# $P<0.001, \mathrm{MIF}^{-/-}$FrD vs WT FrD; ${ }^{+} P<0.05,{ }^{\dagger+} P<0.001, \mathrm{MIF}^{-1-}$ FrD vs $\mathrm{MIF}^{-1-}$.

MIF-/- mice (Fig. 4). Namely, the increase of Fas was detected in VAT of these animals in comparison to WT animals irrespective of the diet $(P<0.01)$, and also in comparison to $\mathrm{MIF}^{-1-}$ mice on standard diet $(P<0.05)$. Acc mRNA level was also increased in $\mathrm{MIF}^{-/-}$mice in comparison to WT $(P<0.001)$, fructose-fed WT $(P<0.01)$ and normally fed $\mathrm{MIF}^{-1-}(P<0.05)$ mice. Pepck mRNA level was significantly increased in Mif-deficient mice on fructose diet in comparison to all other experimental groups $(P<0.001)$. However, mRNA level for the main lipolytic enzyme Atgl was also significantly higher in fructose-fed $\mathrm{MIF}^{-/-}$mice compared to both WT groups (standard diet: $P<0.001$; fructose diet: $P<0.01$ ), as well as compared to normally fed $\mathrm{MIF}^{-}--(P<0.01)$. Interestingly, the level of Hsl mRNA was unchanged (Fig. 4). In addition, Lpl mRNA was increased in fructose-fed WT mice, and in both $\mathrm{MIF}^{-/-}$mice on standard and fructose diet in comparison to the WT animals $(P<0.05, P<0.01$, $P<0.001$, respectively), but also in $\mathrm{MIF}^{-/-}$mice compared to fructose-fed $\mathrm{MIF}^{-/-}$animals $(P<0.01)$.
A

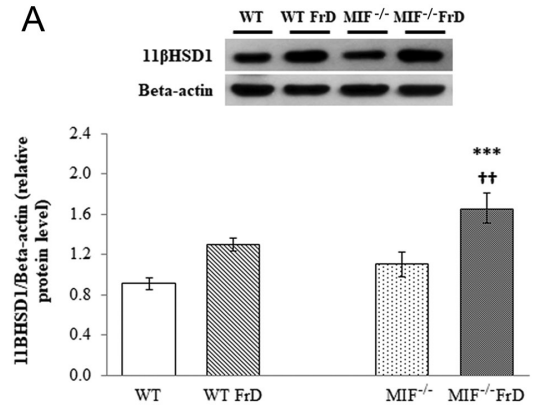

C
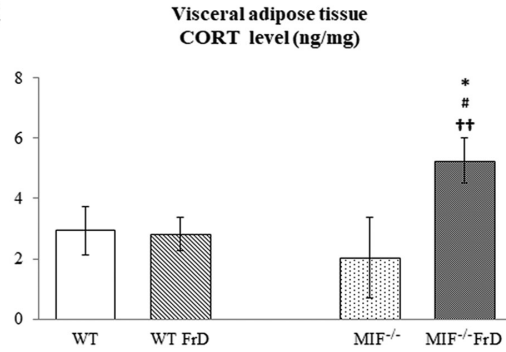

B

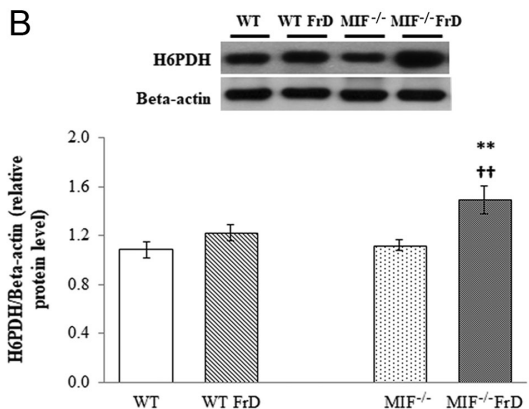

D

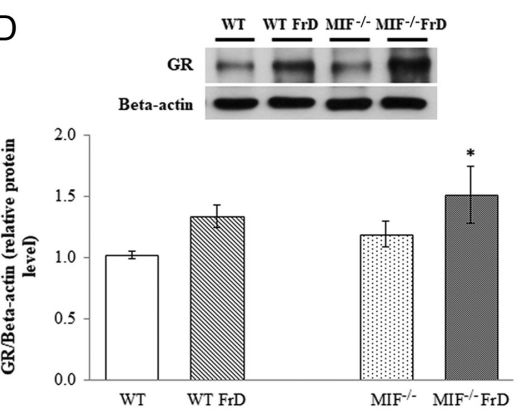

\section{Figure 3}

Glucocorticoid prereceptor metabolism and signaling. Representative Western blots and relative quantification of 11BHSD1 (A), H6PDH (B) and GR (D) protein levels and CORT concentration (C) in total protein extract of VAT from C57BL/6] mice (WT), WT mice on fructose diet (WT FrD),

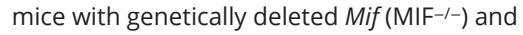
$\mathrm{MIF}^{-/-}$mice on fructose diet (MIF-/- FrD). Data are presented as mean \pm S.E.M. $(n=12$ animals per group). A value of $P<0.05$ was considered statistically significant. Two-way ANOVA showed significant effects of fructose $(P<0.01)$ and Mif deficiency $(P<0.05)$ for both 11BHSD1 and H6PDH protein level, while GR was affected only by fructose treatment $(P<0.01)$. CORT concentration in VAT was affected by fructose diet $(P<0.05)$, as well as by its interaction with Mif deficiency $(P<0.05)$. Significant between-group differences from post hoc Tukey test are given as follows: ${ }^{*} P<0.05,{ }^{* *} P<0.01,{ }^{* * *} P<0.001$, all groups vs WT; ${ }^{\sharp} P<0.05, \mathrm{MIF}^{-1-}$ FrD vs WT FrD; ${ }^{+\dagger} P<0.01$, $\mathrm{MIF}^{-/-}$FrD vs $\mathrm{MIF}^{-/}$. 


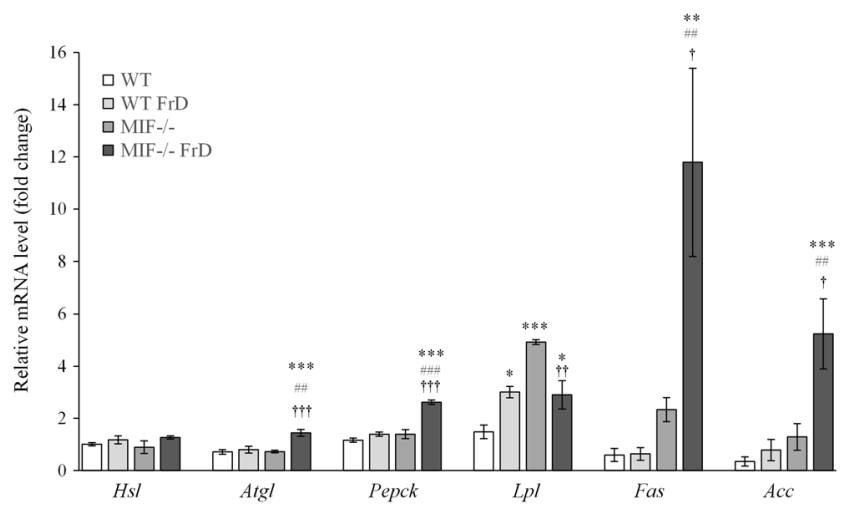

Figure 4

Relative levels of mRNA for genes involved in VAT lipid metabolism. Relative quantification Hsl, Atgl, Pepck, Lpl, Fas and Acc mRNA level, normalized to Hprt1 housekeeping gene, in the VAT of C57BL/6J mice (WT), WT mice on fructose diet (WT FrD), mice with genetically deleted $M i f\left(\mathrm{MIF}^{-/-}\right)$and $\mathrm{MIF}^{-1-}$ mice on fructose diet (MIF-/- FrD). Data are presented as mean \pm S.E.M. ( $n=12$ animals per group) of the triplicate analysis of RNA samples. A value of $P<0.05$ was considered statistically significant. According to two-way ANOVA the effect of fructose was detected for $\operatorname{Atgl}(P<0.001)$, Pepck $(P<0.001)$, Fas $(P<0.05)$ and Acc $(P<0.05)$ mRNA levels. Mif deficiency significantly affected expression of $\operatorname{Atgl}(P<0.01)$, Pepck $(P<0.001)$, Lpl $(P<0.001)$, Fas $(P<0.01)$ and Acc $(P<0.01)$. Interaction between fructose and the absence of MIF was detected for Atgl $(P<0.01)$, Pepck $(P<0.001)$, Lpl $(P<0.001)$, Fas $(P<0.05)$ and Acc $(P<0.05)$ mRNA levels. Significant between-group differences from post hoc Tukey test are given as follows:

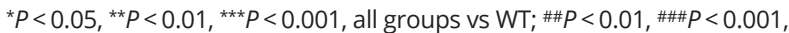
$\mathrm{MIF}^{-/-}$FrD vs WT FrD; ${ }^{\dagger} P<0.05,{ }^{t+} P<0.01,{ }^{+{ }^{\dagger}} P<0.001, \mathrm{MIF}^{-/-}$FrD vs MIF ${ }^{-/-}$.

Protein levels of key transcriptional regulators involved in adipogenesis and lipogenesis, PPARG and SREBP1c, were determined in VAT total protein extract (Fig. 5). PPARG was increased in $\mathrm{MIF}^{-/-}$mice on fructose diet, as compared to WT and $\mathrm{MIF}^{-/-}$animals $(P<0.05)$, while SREBP1c protein level was significantly increased in the same group of animals compared to WT $(P<0.001)$ and both fructose-fed WT and MIF-/- $(P<0.01)$.

\section{Discussion}

Many studies have indicated the importance of MIF for glucose homeostasis, however, its role in metabolic disturbances is less clear. In our study, Mif-deficient mice were hyperglycemic, hyperinsulinemic and had impaired insulin sensitivity. On the other hand, energy-rich fructose diet in $\mathrm{MIF}^{-/-}$mice resulted in increased visceral adiposity, underlaid by stimulated expression of lipogenic genes and the activation of key transcriptional regulators of VAT adipogenesis and lipogenesis, PPARG and SREBP1c. These metabolic perturbations in Mif-deficient mice might be a result of enhanced VAT glucocorticoid signaling in the hyperinsulinemic setting. The deregulated glucocorticoid signaling in the absence of MIF possibly contributes to the stimulation of lipogenic program under the conditions of caloric overload induced by high-fructose diet.

Increasing evidence suggests that in obesity, MIF is released by the adipose tissue and that it is also involved in inflammatory and metabolic processes underlying the development of T2D. Namely, it was already shown that MIF influences glucose metabolism at several levels, including secretion of insulin from pancreas (Waeber et al. 1997), modulation of skeletal muscle and adipose tissue glycolysis, as well as adipocyte insulin resistance mediated by TNFA (Toso et al. 2008). In our study the hallmarks of systemic insulin resistance were observed in all $\mathrm{MIF}^{-/-}$mice, regardless of the diet regimen and
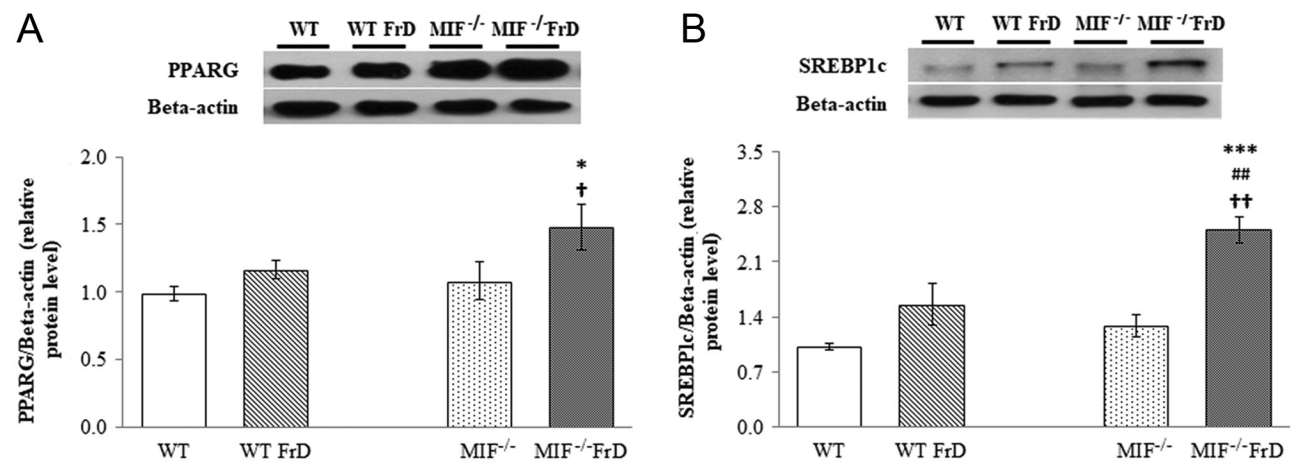

\section{Figure 5}

Transcriptional regulators of VAT lipid metabolism. Representative Western blots and relative quantification of PPARG (A) and SREBP1C (B) total protein levels in the VAT of C57BL/6J mice (WT), WT mice on fructose diet (WT FrD), mice with genetically deleted Mif (MIF-/-) and MIF-/- mice on fructose diet (MIF-/- FrD). Beta-actin was used as a loading control. Data are presented as mean \pm S.E.M. ( $n=12$ animals per group). A value of $P<0.05$ was considered statistically significant. Two-way ANOVA showed significant effects of fructose diet on both PPARG $(P<0.01)$ and SREBP1C $(P<0.001)$, while the deficiency of Mif affected only SREBP1c protein level $(P<0.01)$. Between-group differences from post hoc Tukey test are given as follows: ${ }^{*} P<0.05$, ${ }^{* *} P<0.001$, all groups vs WT; $\# P<0.01, \mathrm{MIF}^{-1-}$ FrD vs WT FrD; ${ }^{\dagger} P<0.05,{ }^{\dagger \dagger} P<0.01, \mathrm{MIF}^{-/-} \mathrm{FrD}$ vs $\mathrm{MIF}^{-/-}$. 
adiposity. Namely, all Mif-deficient mice exhibited hyperglycemia, hyperinsulinemia and impaired glucose and insulin tolerance. However, other authors revealed different results on the role of MIF in the regulation of glucose homeostasis. Verschuren et al. (2009) reported unaltered adiposity, decreased fasting insulin and glucose levels and improved glucose tolerance and insulin sensitivity in Mif-deficient LDLR ${ }^{-/}$mice. In consistence with this, Finucane et al. (2014) demonstrated that obese $\mathrm{MIF}^{-/-}$mice are partially protected from insulin resistance evoked by high-fat diet, since both GTT and ITT AUC values were significantly lower in these mice compared to the WT animals. On the other hand, there are studies showing that $\mathrm{MIF}^{-/-}$mice exhibit disturbed glucose homeostasis and signs of obesity. Serre-Beinier et al. (2010) showed that the absence of MIF led to impaired glucose tolerance, hyperinsulinemia and increased body fat mass in mature mice compared to the WT. Interestingly, Nikolic et al. (2013b) demonstrated that Mif deficiency evokes hyperglycemia and blunted glucose tolerance, but the animals had normal insulin levels and remain responsive to exogenous insulin administration. In addition, the same group of authors showed that insulin resistance appears in $\mathrm{MIF}^{-/-}$mice, but after the introduction of high-fat diet (Saksida et al. 2012). These contradictory findings point to the complexity of MIF's role in glucose and energy metabolism, which could clearly be diet and age dependent. Also, human studies suggest that Mif gene polymorphism contributes to abdominal obesity in a sexspecific manner, since it is related to higher T2D risk in men alone (Coban et al. 2015). Our results confirmed the presence of glucose intolerance in $\mathrm{MIF}^{-/-}$mice, which was further aggravated by fructose diet. Furthermore, we have also observed impaired insulin sensitivity in these animals, but it was not additionally affected by fructose diet. One of the possible reasons for such a discrepancy in the results from different studies could be found in the age of experimental animals. It was already shown that mature adult mice, like those used in the present study, are more prone to insulin resistance and obesity than the young ones (Serre-Beinier et al. 2010).

Besides regulating glucose metabolism, MIF may also be linked to disturbed energy metabolism under caloric overload (Finucane et al. 2014, Kim et al. 2015). Thus one study reported that Mifdeficiency in C57BL/6 mice kept on high-fat diet has adverse effects on glucose tolerance and promotes weight gain, while adipose tissue inflammation was reduced in the absence of MIF (Heinrichs et al. 2014). The present study demonstrated increased visceral adiposity and adipocyte hypertrophy only in $\mathrm{MIF}^{-/-}$mice on fructose diet, which points out the importance of MIF in the development of obesity induced by fructose feeding. Possible mechanism underlying this finding could be found in plasma leptin levels. Taking into account that our Mif-deficient mice had higher insulin levels and that increased insulin levels directly correlate with plasma leptin levels (Askari et al. 2010) and expanding adipose tissue (Makki et al. 2013), it is possible that increased VAT mass in $\mathrm{MIF}^{-/-}$animals contributes to the elevation of circulatory leptin levels. Indeed, in the present study both standard-fed and fructose-fed Mif-deficient mice had increased leptin levels compared to the WT ones, which is in accordance with the study by Saksida et al. (2012) that also showed increased leptin levels in high-fat fed $\mathrm{MIF}^{-/-}$ mice compared to the WT ones, at the time when weight gain between the two strains was observed.

The other important hormonal factors interfering with MIF activity are the GCs. It was previously established that their physiological concentrations could increase MIF expression and secretion, but there are also evidence showing vice versa. Namely, MIF can limit GCs effects, most likely through p38 phosphorylation, while the absence of endogenous MIF is associated with increased sensitivity to GCs through decreased phosphorylation of p38 MAPK (Calandra et al. 1995, Aeberli et al. 2006a,b). Proinflammatory p38 kinase is activated by oxidative stress and inflammation in 3T3-L1 cells and human adipocytes (Merkel et al. 2002, Chuang et al. 2010, Vazquez Prieto et al. 2015, Cheng et al. 2017), and fructose diet is known to enhance the production of proinflammatory cytokines and oxidative stress mediators in rodent visceral adipose tissue (Kovačević et al. 2016, Pektas et al. 2016). Our results showed that fructose diet indeed led to the elevation in both total and phospho p38 protein levels in WT and Mif-deficient mice. However, p38 activity (represented as the ratio of phospho-p38 to total p38) was increased only in fructose-fed mice, which implies that increase of $\mathrm{p} 38$ activation is independent of Mif deficiency.

Indeed, VAT CORT was elevated in these animals, most likely as a result of enhanced glucocorticoid prereceptor metabolism, as revealed by elevated 11BHSD1 and H6PDH protein levels in VAT of fructose-fed MIF-/mice. These results are in accordance with human and animal studies showing that fructose can elevate 11BHSD1 gene expression in VAT (London \& Castonguay 2011), which can further increase visceral adiposity and have deleterious metabolic effects (Walker 2006, Atsumi et al. 2007, Nikolic et al. 2013a). As expected, increased VAT CORT and glucocorticoid prereceptor metabolism were accompanied with elevated GR protein level in VAT of 
fructose-fed MIF-/- mice. However, Nikolic et al. (2013b) reported lower GR expression in the adipose tissue and elevated plasma CORT, while Conboy et al. (2011) found unchanged plasma CORT in Mif-deficient mice. Although there is evidence that elevated glucocorticoids in Mif-deficient mice are involved in the impaired glucose tolerance and immunosuppression (Nikolic et al. 2013b), their effects on VAT lipid metabolism are still largely unknown.

In the adipose tissue, GCs can modulate both lipogenesis and lipolysis (Wang et al. 2012). However, direction of these effects on adipose tissue lipid storage crucially depends on the nutritional and/or hormonal conditions (Kleemann \& Bucala 2010, Peckett et al. 2011, Saksida et al. 2013). GCs can increase the expression of numerous genes involved in lipogenesis and fat deposition, acting synergistically with supraphysiological insulin levels (Campbell et al. 2011). In the present study, the main resultant of fructose consumption combined with Mif deficiency was the activation of glucocorticoidregulated enzymes involved in VAT de novo lipogenesis. Namely, the significant increase of Fas and Acc mRNA levels was observed in VAT of fructose-fed MIF-/- mice, which are both critically involved in de novo lipogenesis (Strable \& Ntambi 2010). They are under direct transcriptional control of SREBP1c (Mandard \& Kersten 2006), which is known to be regulated by both GCs and insulin (Kim et al. 1998, Foretz et al. 1999, Ayala-Sumuano et al. 2013). Indeed, SREBP1c was significantly increased in the VAT of fructose-fed MIF-l- mice, which was consistent with the observed hypertrophic state of adipocytes. Yet, another transcriptional regulator involved in adipogenesis, PPARG, was also significantly increased in the VAT of the same animals. Previous studies, investigating the role of MIF in adipogenesis, showed that $\mathrm{MIF}^{-/-}$cells had elevated PPARG expression during adipocyte differentiation (Atsumi et al. 2007). However, in our study, significant effect on PPARG protein level was observed only when MIF-/- mice were fed with fructose, while it was not changed either in $\mathrm{MIF}^{-/-}$mice on standard diet or in the fructose-fed WT mice, which implies that fructoserich diet generates both adipogenesis and hypertrophy only in the absence of Mif and in the presence of enhanced glucocorticoid signaling. On the other hand, in the fructose-fed $\mathrm{MIF}^{-/}$- mice, glucocorticoid-mediated lipolysis was not observed. Although Atgl expression was increased, it was not accompanied with increased plasma FFA release, possibly due to increased Pepck and Lpl expression, known to be involved in FFA re-esterification in the adipose tissue (Merkel et al. 2002). These results shed new light on the role of MIF in the diet-induced obesity, where Mif deficiency promotes visceral adiposity under the conditions of energy overload.

In conclusion, the present study showed that Mif deficiency is important for the development of glucose and insulin resistance. The metabolic stress, in the form of energy-rich fructose diet, led to visceral adiposity and adipocyte hypertrophy in Mif-deficient mice, concomitantly with stimulated adipose tissue lipogenesis. We assume that these harmful effects of Mif deficiency might be conducted through the enhanced glucocorticoid prereceptor metabolism and glucocorticoid-facilitated lipogenesis in the VAT, a proposal deserving further exploration. In that case, Mif deficiency might be a crucial factor for glucocorticoid-mediated adiposity in response to fructose-enriched diet, providing a setting for hyperinsulinemia and insulin resistance.

\section{Declaration of interest}

The authors declare that there is no conflict of interest that could be perceived as prejudicing the impartiality of the research reported.

\section{Funding}

This work was supported by the Ministry of Education, Science and Technological Development of the Republic of Serbia (Grant No III41009) and by 'Start Up for Science' grant from the Center for Leadership Development.

\section{Author contribution statement}

Ljupka Gligorovska conducted the experiments, analyzed the data and wrote the paper. Biljana Bursać provided experimental help, Sanja Kovačević performed histological analyses. Nataša Veličković and Gordana Matić revised the paper before submission. Ana Djordjevic designed the study and revised the paper before submission.

\section{Acknowledgement}

The authors are thankful to Dr Stanislava Stošić Grujičić and Dr Ivana Stojanović for providing experimental animals.

\section{References}

Aeberli D, Yang Y, Mansell A, Santos L, Leech M \& Morand EF $2006 a$ Endogenous macrophage migration inhibitory factor modulates glucocorticoid sensitivity in macrophages via effects on MAP kinase phosphatase-1 and p38 MAP kinase. FEBS Letters 580 974-981. (https://doi.org/10.1016/j.febslet.2006.01.027)

Aeberli D, Leech M \& Morand EF 2006b Macrophage migration inhibitory factor and glucocorticoid sensitivity. Rheumatology 45 937-943. (https://doi.org/10.1093/rheumatology/kel142) 
Askari H, Tykodi G, Liu J \& Dagogo-Jack S 2010 Fasting plasma leptin level is a surrogate measure of insulin sensitivity. Journal of Clinical Endocrinology and Metabolism 95 3836-3843. (https://doi.org/10.1210/ jc.2010-0296)

Atsumi T, Cho Y-R, Leng L, McDonald C, Yu T, Danton C, Hong E-G, Mitchell RA, Metz C, Niwa H, et al. 2007 The proinflammatory cytokine macrophage migration inhibitory factor regulates glucose metabolism during systemic inflammation. Journal of Immunology 179 5399-5406. (https://doi.org/10.4049/jimmunol.179.8.5399)

Ayala-Sumuano J-T, Velez-delValle C, Beltrán-Langarica A, MarschMoreno M, Hernandez-Mosqueira C \& Kuri-Harcuch W 2013 Glucocorticoid paradoxically recruits adipose progenitors and impairs lipid homeostasis and glucose transport in mature adipocytes. Scientific Reports 3 2573. (https://doi.org/10.1038/srep02573)

Basciano H, Federico L \& Adeli K 2005 Fructose, insulin resistance, and metabolic dyslipidemia. Nutrition and Metabolism 2 5. (https://doi. org/10.1186/1743-7075-2-5)

van Beek L, van Klinken JB, Pronk ACM, van Dam AD, Dirven E, Rensen PCN, Koning F, Willems van Dijk K \& van Harmelen V 2015 The limited storage capacity of gonadal adipose tissue directs the development of metabolic disorders in male C57Bl/6J mice. Diabetologia 58 1601-1609. (https://doi.org/10.1007/s00125-015-3594-8)

Bjørndal B, Burri L, Staalesen V, Skorve J \& Berge RK 2011 Different adipose depots: their role in the development of metabolic syndrome and mitochondrial response to hypolipidemic agents. Journal of Obesity 2011 490650. (https://doi.org/10.1155/2011/490650)

Calandra T \& Bucala R 1997 Macrophage migration inhibitory factor (MIF): a glucocorticoid counter-regulator within the immune system. Critical Reviews in Immunology 17 77-88. (https://doi.org/10.1615/ CritRevImmunol.v17.i1.30)

Calandra T, Bernhagen J, Metz CN, Spiegel LA, Bacher M, Donnelly T, Cerami A \& Bucala R 1995 MIF as a glucocorticoid-induced modulator of cytokine production. Nature 377 68-71. (https://doi. org/10.1038/377068a0)

Campbell JE, Peckett AJ, D'souza AM, Hawke TJ \& Riddell MC 2011 Adipogenic and lipolytic effects of chronic glucocorticoid exposure. American Journal of Physiology-Cell Physiology 300 C198-C209. (https://doi.org/10.1152/ajpcell.00045.2010)

Chakravarty K, Cassuto H, Reshef L \& Hanson RW 2005 Factors that control the tissue-specific transcription of the gene for phosphoenolpyruvate carboxykinase-C. Critical Reviews in Biochemistry and Molecular Biology $\mathbf{4 0}$ 129-154. (https://doi.org/10.1080/10409230590935479)

Cheng P-W, Lin Y-T, Ho W-Y, Lu P-J, Chen H-H, Lai C-C, Sun G-C, Yeh T-C, Hsiao M, Tseng C-J, et al. 2017 Fructose induced neurogenic hypertension mediated by overactivation of p38 MAPK to impair insulin signaling transduction caused central insulin resistance. Free Radical Biology and Medicine 112 298-307. (https://doi.org/10.1016/j. freeradbiomed.2017.07.022)

Chuang C-C, Martinez K, Xie G, Kennedy A, Bumrungpert A, Overman A, Jia W \& McIntosh MK 2010 Quercetin is equally or more effective than resveratrol in attenuating tumor necrosis factor- $\alpha$-mediated inflammation and insulin resistance in primary human adipocytes. American Journal of Clinical Nutrition 92 1511-1521. (https://doi. org/10.3945/ajcn.2010.29807)

Church TS, Willis MS, Priest EL, LaMonte MJ, Earnest CP, Wilkinson WJ, Wilson DA \& Giroir BP 2005 Obesity, macrophage migration inhibitory factor and weight loss. International Journal of Obesity 29 675-681. (https://doi.org/10.1038/sj.ijo.0802942)

Chusyd DE, Wang D, Huffman DM \& Nagy TR 2016 Relationships between rodent white adipose fat pads and human white adipose fat depots. Frontiers in Nutrition 3 10. 10. (doi:10.3389/fnut.2016.00010)

Coban N, Onat A, Yildirim O, Can G \& Erginel-Unaltuna N 2015 Oxidative stress-mediated (sex-specific) loss of protection against type-2 diabetes by macrophage migration inhibitory factor (MIF)173G/C polymorphism. Clinica Chimica Acta 438 1-6. (https://doi. org/ 10.1016/j.cca.2014.07.037)
Conboy L, Varea E, Castro JE, Sakouhi-Ouertatani H, Calandra T, Lashuel HA \& Sandi C 2011 Macrophage migration inhibitory factor is critically involved in basal and fluoxetine-stimulated adult hippocampal cell proliferation and in anxiety, depression and memory-related behaviors. Molecular Psychiatry 16 533-547. (https://doi.org/10.1038/mp.2010.15)

Cvetkovic I, Al-Abed Y, Miljkovic D, Maksimovic-Ivanic D, Roth J, Bacher M, Lan HY, Nicoletti F \& Stosic-Grujicic S 2005 Critical role of macrophage migration inhibitory factor activity in experimental autoimmune diabetes. Endocrinology 146 2942-2951. (https://doi. org/10.1210/en.2004-1393)

Djordjevic A, Milutinović DV, Tanić N, Bursać B, Vasiljević A, Veličković N, Elaković I \& Matić G 2012 Identification of suitable reference genes for gene expression studies in tissues from fructose-fed rats. Advanced Science Letters 5 560-565. (https://doi.org/10.1166/asl.2012.2186)

Eberlé D, Hegarty B, Bossard P, Ferré P \& Foufelle F 2004 SREBP transcription factors: master regulators of lipid homeostasis. Biochimie 86 839-848. (https://doi.org/10.1016/j.biochi.2004.09.018)

Fingerle-Rowson G, Petrenko O, Metz CN, Forsthuber TG, Mitchell R, Huss R, Moll U, Muller W \& Bucala R 2003 The p53-dependent effects of macrophage migration inhibitory factor revealed by gene targeting. PNAS 100 9354-9359. (https://doi.org/10.1073/pnas.1533295100)

Finucane OM, Reynolds CM, McGillicuddy FC \& Roche HM 2012 Insights into the role of macrophage migration inhibitory factor in obesity and insulin resistance. Proceedings of the Nutrition Society 71 622-633. (https://doi.org/10.1017/S0029665112000730)

Finucane OM, Reynolds CM, McGillicuddy FC, Harford KA, Morrison M, Baugh J \& Roche HM 2014 Macrophage migration inhibitory factor deficiency ameliorates high-fat diet induced insulin resistance in mice with reduced adipose inflammation and hepatic steatosis. PLOS ONE 9 1-14. (https://doi.org/10.1371/journal.pone.0113369)

Foretz M, Guichard C, Ferré P \& Foufelle F 1999 Sterol regulatory element binding protein-1c is a major mediator of insulin action on the hepatic expression of glucokinase and lipogenesis-related genes. PNAS 96 12737-12742. (https://doi.org/10.1073/pnas.96.22.12737)

Galarraga M, Campión J, Muñoz-Barrutia A, Boqué N, Moreno H, Martínez JA, Milagro F \& Ortiz-de-Solórzano C 2012 Adiposoft: automated software for the analysis of white adipose tissue cellularity in histological sections. Journal of Lipid Research 53 2791-2796. (https://doi.org/10.1194/jlr.D023788)

Heinrichs D, Berres M-L, Coeuru M, Knauel M, Nellen A, Fischer P, Philippeit C, Bucala R, Trautwein C, Wasmuth HE, et al. 2014 Protective role of macrophage migration inhibitory factor in nonalcoholic steatohepatitis. FASEB Journal 28 5136-5147. (https:// doi.org/10.1096/fj.14-256776)

Kim JB, Sarraf P, Wright M, Yao KM, Mueller E, Solanes G, Lowell BB \& Spiegelman BM 1998 Nutritional and insulin regulation of fatty acid synthetase and leptin gene expression through ADD1/SREBP1. Journal of Clinical Investigation 101 1-9. (https://doi.org/10.1172/JCI1411)

Kim B-S, Pallua N, Bernhagen J \& Bucala R 2015 The macrophage migration inhibitory factor protein superfamily in obesity and wound repair. Experimental and Molecular Medicine 47 e161. (https://doi. org/10.1038/emm.2015.26)

Kleemann R \& Bucala R 2010 Macrophage migration inhibitory factor: critical role in obesity, insulin resistance, and associated comorbidities. Mediators of Inflammation 2010 610479. (https://doi. org/10.1155/2010/610479)

Kovačević S, Nestorov J, Matić G \& Elaković I 2016 Fructose and stress induce opposite effects on lipid metabolism in the visceral adipose tissue of adult female rats through glucocorticoid action. European Journal of Nutrition 56 1-14. (https://doi.org/10.1007/s00394-016-1251-8)

Lee M-J, Pramyothin P, Karastergiou K \& Fried SK 2014 Deconstructing the roles of glucocorticoids in adipose tissue biology and the development of central obesity. Biochimica et Biophysica Acta 1842 473-481. (https://doi.org/10.1016/j.bbadis.2013.05.029)

London E \& Castonguay TW 2011 High fructose diets increase 11 $\beta$-hydroxysteroid dehydrogenase type 1 in liver and visceral 
adipose in rats within 24-h exposure. Obesity 19 925-932. (https:// doi.org/10.1038/oby.2010.284)

Lowry OH, Rosebrough NJ, Farr AL \& Randall RJ 1951 Protein measurement with the Folin phenol reagent. Journal of Biological Chemistry 193 265-275.

Makki K, Froguel P \& Wolowczuk I 2013 Adipose tissue in obesityrelated inflammation and insulin resistance: cells, cytokines, and chemokines. ISRN Inflammation 2013 139239. (https://doi. org/10.1155/2013/139239)

Mandard S \& Kersten S 2006 Regulation of lipogenic genes in obesity. In Nutritional Genomics, pp 208-219. Eds Brigelius R \& Joost HG. Weinheim, Germany: Wiley-VCH Verlag GmbH \& Co. KGaA. (https:// doi.org/10.1002/3527608109.ch12)

Mariniello B, Ronconi V, Rilli S, Bernante P, Boscaro M, Mantero F \& Giacchetti G 2006 Adipose tissue 11beta-hydroxysteroid dehydrogenase type 1 expression in obesity and Cushing's syndrome. European Journal of Endocrinology 155 435-441. (https://doi.org/10.1530/eje.1.02228)

Merkel M, Eckel RH \& Goldberg IJ 2002 Lipoprotein lipase: genetics, lipid uptake, and regulation. Journal of Lipid Research 43 1997-2006. (https://doi.org/10.1194/jlr.R200015-JLR200)

Monteiro R \& Azevedo I 2010 Chronic inflammation in obesity and the metabolic syndrome. Mediators of Inflammation 2010289645. (https://doi.org/10.1155/2010/289645)

Morrison MC \& Kleemann R 2015 Role of macrophage migration inhibitory factor in obesity, insulin resistance, type 2 diabetes, and associated hepatic co-morbidities: a comprehensive review of human and rodent studies. Frontiers in Immunology 6 308. (https://doi org/10.3389/fimmu.2015.00308)

Nikolic I, Vujicic M, Saksida T, Berki T, Stosic-Grujicic S \& Stojanovic I $2013 a$ The role of endogenous glucocorticoids in glucose metabolism and immune status of MIF-deficient mice. Archives of Biological Sciences 714 499-505. (https://doi.org/10.1016/j.ejphar.2013.06.037)

Nikolic I, Vujicic M, Saksida T, Berki T, Stosic-Grujicic S \& Stojanovic I $2013 b$ The role of endogenous glucocorticoids in glucose metabolism and immune status of MIF-deficient mice. European Journal of Pharmacology 714 498-506. (https://doi.org/10.1016/j. ejphar.2013.06.037)

Peckett AJ, Wright DC \& Riddell MC 2011 The effects of glucocorticoids on adipose tissue lipid metabolism. Metabolism 60 1500-1510. (https://doi.org/10.1016/j.metabol.2011.06.012)

Pektas MB, Koca HB, Sadi G \& Akar F 2016 Dietary fructose activates insulin signaling and inflammation in adipose tissue: modulatory role of resveratrol. BioMed Research International 2016 1-10. (https://doi. org/10.1155/2016/8014252)

Rosen ED \& Spiegelman BM 2001 PPAR $\gamma$ : a nuclear regulator of metabolism, differentiation, and cell growth. Journal of Biological Chemistry 276 37731-37734. (https://doi.org/10.1074/jbc.R100034200)

Sakaue S, Nishihira J, Hirokawa J, Yoshimura H, Honda T, Aoki K, Tagami S \& Kawakami Y 1999 Regulation of macrophage migration inhibitory factor (MIF) expression by glucose and insulin in adipocytes in vitro. Molecular Medicine 5 361-371.

Saksida T, Stosic-Grujicic S, Timotijevic G, Sandler S \& Stojanovic I 2012 Macrophage migration inhibitory factor deficiency protects pancreatic islets from palmitic acid-induced apoptosis. Immunology and Cell Biology 90 688-698. (https://doi.org/10.1038/icb.2011.89)

Saksida T, Stosic-Grujicic S \& Stojanovic I 2013 The role of macrophage migration inhibitory factor in obesity-associated type 2 diabetes in mice. Archives of Biological Sciences 65 499-505. (https://doi. org/10.2298/ABS1302499S)
Seckl JR, Morton NM, Chapman KE \& Walker BR 2004 Glucocorticoids and 11beta-hydroxysteroid dehydrogenase in adipose tissue. Recent Progress in Hormone Research 59 359-393. (https://doi.org/10.1210/ rp.59.1.359)

Serre-Beinier V, Toso C, Morel P, Gonelle-Gispert C, Veyrat-Durebex C, Rohner-Jeanrenaud F, Calandra T, Roger T, James RW, Montet X, et al. 2010 Macrophage migration inhibitory factor deficiency leads to age-dependent impairment of glucose homeostasis in mice. Journal of Endocrinology 206 297-306. (https://doi.org/10.1677/JOE-09-0342)

Skurk T, Herder C, Kräft I, Müller-Scholze S, Hauner H \& Kolb H 2005 Production and release of macrophage migration inhibitory factor from human adipocytes. Endocrinology 146 1006-1011. (https://doi. org/10.1210/en.2004-0924)

Strable MS \& Ntambi JM 2010 Genetic control of de novo lipogenesis: role in diet-induced obesity. Critical Reviews in Biochemistry and Molecular Biology 45 199-214. (https://doi. org/10.3109/10409231003667500)

Tappy L \& Le K-A 2010 Metabolic effects of fructose and the worldwide increase in obesity. Physiological Reviews 90 23-46. (https://doi. org/10.1152/physrev.00019.2009)

Toso C, Emamaullee JA, Merani S \& Shapiro AMJ 2008 The role of macrophage migration inhibitory factor on glucose metabolism and diabetes. Diabetologia 51 1937-1946. (https://doi.org/10.1007/s00125008-1063-3)

Vazquez Prieto MA, Bettaieb A, Rodriguez Lanzi C, Soto VC, Perdicaro DJ, Galmarini CR, Haj FG, Miatello RM \& Oteiza PI 2015 Catechin and quercetin attenuate adipose inflammation in fructose-fed rats and 3T3-L1 adipocytes. Molecular Nutrition and Food Research 59 622-633. (https://doi.org/10.1002/mnfr.201400631)

Veličković N, Djordjevic A, Vasiljević A, Bursać B, Milutinović DV \& Matić G 2013 Tissue-specific regulation of inflammation by macrophage migration inhibitory factor and glucocorticoids in fructose-fed Wistar rats. British Journal of Nutrition 110 456-465. (https://doi.org/10.1017/S0007114512005193)

Verschuren L, Kooistra T, Bernhagen J, Voshol PJ, Ouwens DM, van Erk M, de Vries-van der Weij J, Leng L, van Bockel JH, van Dijk KW, et al. 2009 MIF deficiency reduces chronic inflammation in white adipose tissue and impairs the development of insulin resistance, glucose intolerance, and associated atherosclerotic disease. Circulation Research 105 99-107. (https://doi.org/10.1161/ CIRCRESAHA.109.199166)

Waeber G, Calandra T, Roduit R, Haefliger JA, Bonny C, Thompson N, Thorens B, Temler E, Meinhardt A, Bacher M, et al. 1997 Insulin secretion is regulated by the glucose-dependent production of islet beta cell macrophage migration inhibitory factor. PNAS 94 4782-4787. (https://doi.org/10.1073/pnas.94.9.4782)

Wajchenberg BL 2000 Subcutaneous and visceral adipose tissue: their relation to the metabolic syndrome. Endocrine Reviews 21 697-738. (https://doi.org/10.1210/edrv.21.6.0415)

Walker BR 2006 Cortisol - cause and cure for metabolic syndrome? Diabetic Medicine 23 1281-1288. (https://doi.org/10.1111/j.14645491.2006.01998.x)

Wang J-C, Gray NE, Kuo T \& Harris CA 2012 Regulation of triglyceride metabolism by glucocorticoid receptor. Cell and Bioscience 219. (https://doi.org/10.1186/2045-3701-2-19)

Yabunaka N, Nishihira J, Mizue Y, Tsuji M, Kumagai M, Ohtsuka Y, Imamura M \& Asaka M 2000 Elevated serum content of macrophage migration inhibitory factor in patients with type 2 diabetes. Diabetes Care 23 256-258. (https://doi.org/10.2337/diacare.23.2.256)

Received in final form 5 October 2018

Accepted 22 October 2018

Accepted Preprint published online 25 October 2018 https://joe.bioscientifica.com https://doi.org/10.1530/JOE-18-0333 (c) 2019 Society for Endocrinology Published by Bioscientifica Ltd.
Printed in Great Britain 